\title{
Shopping malls with quasi-public spaces in Pretoria: Neo-traditional consumption space or controlled village commons?
}

\author{
Karina Landman
}

http://dx.doi.org/10.18820/2415-0495/trp69i1.3

Peer reviewed and revised November 2016

\begin{abstract}
Recent debates have highlighted trends towards the privatisation of public space and the incorporation of increased security measures to safeguard users. Literature has also emphasised the move away from the traditional high street to suburban shopping malls as part of an increased focus on the development of protected consumption space. As public space continuously evolves, it is interesting to find the emergence of a new type of controlled outdoor space that seems to reflect characteristics of older traditional public spaces acting as a local gathering space in suburbia, yet being very controlled within the boundaries of shopping malls and reflecting strong patterns of consumption. The paper investigates this trend within the capital city of South Africa, Pretoria, focusing on three quasi-public spaces. The findings indicate that urban design continues to play a critical role in the incorporation of characteristics that are traditionally associated with successful public spaces, but with a strong emphasis on consumption in a controlled and secure environment. At the same time, however, these spaces have also become a new type of village commons in an increasingly polarised society and, hence, cannot simply be negated as purely exclusive spaces.
\end{abstract}

Key words: Consumption spaces, Pretoria, quasi-public spaces, shopping malls

\section{INKOPIESENTRUMS MET PUBLIEKE RUIMTES IN PRETORIA: NEO-TRADISIONELE VERBRUIKRUIMTE OF BEHEERDE DORP GEMEENSKAPSBESIT?}

Resente debate fokus op die privatisering van publieke ruimtes en die insluiting van meer sekuriteitsmaatreëls om gebruikers te beskerm. Die literatuur beklemtoon ook die beweging weg van tradisionele kernstrate na voorstedelike inkopiesentrums as deel van ' $n$ groter fokus op die ontwikkeling van beskermde verbruiking. Soos wat publieke ruimte heeltyd verander, is dit interessant om te vind dat daar ' $n$ nuwe tipe beskermde buite-ruimte na vore kom wat van die karaktereienskappe van meer tradisionele publieke ruimtes insluit en tog terselfdertyd meer gekontroleerd is binne die grense van inkopiesentrums met sterk verbruikerstendense. Die artikel ondersoek hierdie verskynsel in die hoofstad van Suid-Afrika, Pretoria. Die bevindinge dui daarop dat stedelike ontwerp steeds ' $n$ belangrike rol speel in terme van die insluiting van tipiese karaktereienskappe van suksesvolle publieke ruimtes, maar met 'n sterk fokus op verbruiking binne 'n beskermde omgewing. Terselfdetyd word hierdie nuwe ruimtes ook ' $n$ tipe plaaslike bymekaarkomplek in ' $n$ baie gepolariseerde samelewing en kan dus nie net as suiwer ekslusiewe ruimtes afgeskryf word nie.

Sleutelwoorde: Inkopiesentrums, Pretoria, sogenaamde publieke ruimtes, verbruikersruimtes.

\section{NTSHETSOPELE YA DIBAKA TSEO E SENG TSA NNETE TSA BATHO BOHLE AFRIKA BORWA: SEBAKA SE SETJHA SE TLWAELEHILENG SA TSHEBETSO KAPA SA BATHO BA TLASA TAOLO BA MAHAENG?}

Dipuisano tse sa tswa ba teng di hlalosa mekgwa e latelwang mabapi le ho etsa sebaka sa batho bohle hore e be sa poraefete; le ho kgaohangwa ha mekgwa e ekeditsweng ya tshireletso ho sireletsa basebedisi ba sebaka seo. Hape dingolwa di hatelletse ho sutha seterateng sa sephethephethe se tlwaelehileng; ho ya dimolong kapa dibakeng tsa thekiso tsa metsetoropo e le jwaloka karolo ya mohopolo o tsepameng ho ntshetsopele ya dibaka tse sirelleditsweng. Tsa kgwebo Jwaloka ha sebaka sa batho bohle se ntse se fetoha, ho a kgahlisa ho fumana ho hlahisa mofuta o motjha wa sebaka se kantle se bontshang matshwao a dibaka tsa kgale tse tlwaelehileng tsa batho bohle tse sebetsang jwaloka dibaka tse ka sehloohong moo ho kopanwang teng motsaneng, le ha ho le jwalo; se laolwa haholo ka hara meedi ya dimolo tse fetofetohang tsa metsetoropo, mme di bontsha paterone e matla ya kgwebo. Pampiri ena e batlisisa mokgwa ona o latelwang (trend) ka hara motsemoholo wa Afrika Borwa,Tshwane (Pretoria);mme e tsepamisitse maikutlo hodima dibaka tse tharo tsa toropo. Diphumano/diphetho tsa diphuputso di bontsha hore tsela eo toropo e hlophiswang ka yona e tswellapele ho bapala karolob ya bohlokwa bakeng sa ho kopanya matshwao ao esale a amahantswe le dibaka tsa batho bohle tse atlehileng; empa ka kgatello e matla hodima kgwebisano ka mokgwa o kgutsitseng le tikolohong e bolokehileng. Le ha ho le jwalo, ka yona nako eo; dibaka tsena di fetohile mokgwa o motjha wa motsana wa batho ba arohaneng ka maikutlo le setjhaba se sa bolokehang; mme ke ka hoo di sa kgoneng ho latolwa feela jwaloka dibaka tse ka thoko.

\section{INTRODUCTION}

South African cities have experienced dramatic changes over the past twenty years. Influenced by major political and governance transformation since 1994 and accompanied by large-scale urbanisation, cities have become not only places of socio-economic opportunity, but also arenas for increased conflict and contestation. In this context, the public realm does not only cater for a diverse population and income groups, but also acts 
as a stage for unwanted encounters between people with various needs and images of what public space should be (Landman, 2016). Traditional public spaces have gradually changed to accommodate a variety of patrons and cultures alongside different types of activities. While this has been welcomed by some, it has been shunned by others, creating a gap in the market for a new type of quasi-public and controlled outdoor space that seems to reflect characteristics of more traditional public spaces acting as a local gathering space, but at the same time being strictly controlled within the boundaries of changing suburban malls and reflecting strong patterns of consumption. It, therefore, begs the question: Are these neotraditional consumption spaces or rather a controlled village commons?

Village commons, in this context, should not be strictly interpreted in the narrow sense of being the communal gathering space of the old village where the community used to gather and livestock grazed, but rather as a traditional gathering space in a town - whether marketplace, civic or religious centre - where residents came together to see and be seen, or to engage in a variety of activities. Public places often played this role in history. For example, the Piazza del Populo in Rome acted as the civic centre; the enclosed cathedral square in Livorno was the religious centre, very different to the rowdiness of the great open piazza on the harbour front of the town - a typical marketplace (Kostof, 1992).

In a general sense or as an ideal type, "a public space is provided by the public authorities, concerns the people as a whole, is open or available to them, and is used or shared by all members of the community" (Madanipour, 1999: 881). However, as Madanipour (1999) explains, each of these can represent a wide range of possibilities such as, for example, the extent to which public authorities serve the community, the availability of space depending on a complex set of rules, and the willingness or ability of different members of a community or neighbourhood to use or experience meaning related to a particular space. Given this, a more accurate definition of public space would refer to "places outside the boundaries of individual or small-group control, mediating between private spaces and used for a variety of often overlapping functional and symbolic purposes" (Madanipour, 1999: 881). These purposes may include a number of activities such as meeting neighbours and colleagues, taking part in social events, obtaining information about the social environment, gaining inspiration for action, and engaging in a stimulating experience (Gehl, 2011: 19-21).

This raises several questions related to the nature of public spaces in a democratic South Africa. Should all public spaces be provided by public authorities, open to all and used and shared by everyone in society? What does the development of quasi-public space mean for urban planning and design? This article offers a framework to understand the characteristics of successful public spaces and analyse the transformation thereof within a changing context. Together with the continuous urbanisation of South African cities, large metropolitan areas are increasingly expanding outwards to accommodate new suburban developments. Shopping malls are a popular destination point and characteristic of suburbia. While there is a growing debate on the relevance of shopping malls in contemporary cities and the drivers behind their development, it is not the intention of this paper to investigate the power or economics of real estate. The focus is rather on the new quasi-public spaces that emerge within these shopping malls. Therefore, utilising the framework illustrating the characteristics of successful public spaces, the paper explores three emerging quasi-public spaces in the City of Tshwane and, considering the findings, discusses some implications thereof for urban planning and design in South Africa.

\section{CHARACTERISTICS OF SUCCESSFUL TRADITIONAL PUBLIC SPACES}

Many scholars, urbanists and designers have written about the characteristics of public spaces. It is not the purpose of this paper to offer a detailed account of these, but rather to summarise the key characteristics to assist in understanding the transformation of public spaces and the emergence of quasi-public plazas within the City of Tshwane. In an attempt to offer a way in which to recognise a successful urban place, Montgomery (1998), in taking further work by Canter (1977) and Punter (1991), summarised the components of a sense of place by focusing on three overlapping categories, namely activity, form and image. Although Montgomery's framework touches on detail aspects, it tends to focus more on a sense of place at the precinct or district level. Similarly, Talen (2000) developed a framework to examine the characteristics of physical space that would facilitate a greater sense of community. While referring to detail aspects, it mainly considers the public realm at a neighbourhood level. This paper focuses only on individual public spaces at the level of the site, adapting existing work to offer a framework to describe the specific characteristics of successful public places on a smaller scale. Taking into account recent publications on public space, it is possible to conceptualise a framework based on three interlinked categories, namely form, function and meaning, in order to identify the different items that constitute a successful public space. Function is primarily concerned with the uses and activities taking place in a public space, while form is concerned with the organisation of the physical elements. Meaning reflects the interpretation of space based on the function and form. As these change, the meaning of public space is constantly changing, due to competing ideas, differing values, and antagonistic political or economic forces that influence the behaviour and use of 
space (Kostof, 1992; Short, 1996).

Changing social and physical constructs, therefore, change the meaning of public space (Kostof, 1992; Sorkin, 1992; Amin, 2008).

While public spaces generally include streets, squares/plazas and parks, this article exclusively focuses on squares or plazas. Thus, while most of the characteristics can be applicable to all three types, some may be more related to public squares or hard open places, in particular. Moughton and Mertens (2003) state that a square or plaza can be categorised either based on function or form and that these spaces embody a specific meaning. Table 1 in Appendix A summarises the three categories and the justification for their various items.

New Urbanists have also advocated the development of public spaces with similar characteristics. This has gained increasing momentum through spatial initiatives such as urban villages, transit-oriented developments, and other variations of New Urbanism (Talen, 2000). Yet, although these characteristics have been promoted as a normative ideal, it has not always been implemented in practice. Public space has often been restricted to certain social groups such as the elderly, the young, women or members of certain sexual and ethnic minorities who have been excluded or subjected to political or moral censure (Jackson, 1998; Madanipour, 2010). In recent years, shopping malls, in particular, have been criticised for facilitating exclusive spaces for higher income groups (Matson, 1999; Minton, 2006; Carmona, 2010).

\section{THE TRANSFORMATION OF CONTEMPORARY PUBLIC SPACE}

Although many urbanists and designers continuously emphasise the significance of public space in cities, there have been increasing trends in the privatisation of public space and the loss of public life (Kohn, 2004; Low \& Smith, 2006; Loukaitou-Sideris, 2012). Often, when writing about public space, authors bemoan the decline of its quality and the loss of character (De Magalhaes, 2010), due to a growing perception that public spaces are dangerous places of potential conflict linked to public incivilities and a loss of territorial control (Tiesdell \& Oc, 1998; Carmona, 2010; Banarjee, 2011). These trends, combined with perceptions of changing and inner city decline,

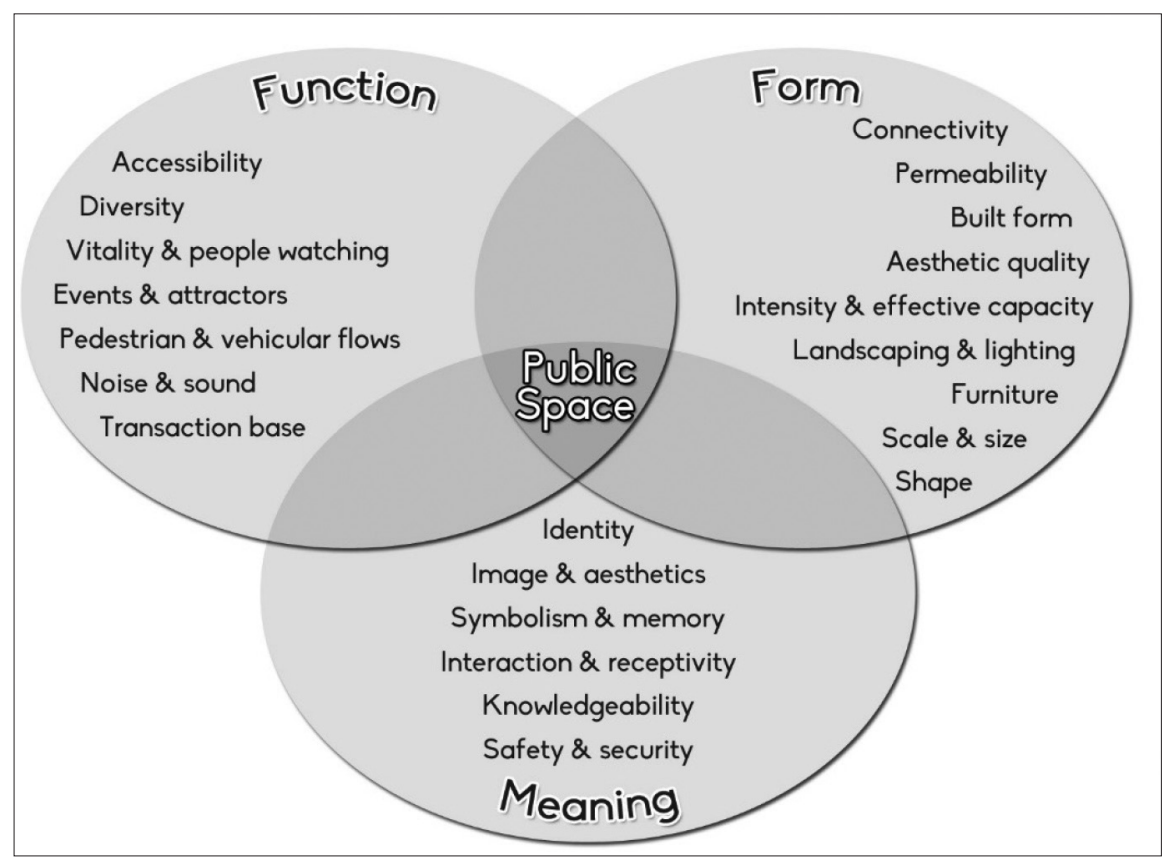

Figure 1: Characteristics of successful public spaces

encouraged increasing privatisation (Giddings, Charlton \& Horne, 2011).

The privatisation of public space refers to a process where there has been a shift in the provision and management of public space away from direct state involvement towards a larger role for other stakeholders, including large corporates, developers, real-estate companies and community or volunteer sectors (De Maghalaes, 2010: 559). The result has often been the demise of truly public space and the emergence of 'pseudo-public places' (Banerjee, 2001) or 'private public spaces' (De Magalaes, 2010), which include corporate plazas and open spaces, shopping malls, or public spaces managed by private interests through, for example, Business Improvement Districts. Although some of these changes involved attempts by community organisations or business interests to assist financially strapped public authorities with the development and management of declining public spaces (Madanipour, 1999; De Maghalaes, 2010), they have also been regarded as deliberate strategies by large corporates and developers to improve profits (Christopherson, 1994; Jackson, 1998; De Maghalaes, 2010). Commercialisation and shopping malls have thus been blamed for the privatisation of public space (Langstraat \& Van Melik, 2013).

This trend towards greater privatisation also influences the classification of contemporary public spaces. Webster (2007) maintains that there is a continuum of different types of public spaces that are dependent on the levels of excludability and rivalry that take place within these spaces. Urban space tends to evolve from being non-excludable and non-rival, to non-excludable and rival, to excludable and non-rival and, finally, to excludable and rival. The first category refers to a pure public good, whereas the second category tends to be institutionally unstable and in need of property rights reassignment. The third category of urban space is a 'club' good and is stable, whereas the governing organisation can 
maintain control over the quantity and quality of space available and the members or consumers. The last category is a pure private space.

In a pure sense, the public domain would refer to a sphere of resource consumption within which consumption rights remain unallocated. However, as public space evolves from one type to another, three factors, namely congestion, separation of attributes and ownership, would influence the use and allocation of these spaces within the public domain. The level of congestion within the public domain depends on the amount of public space available, the number of individuals who use it at a particular time and the range of preferences of those individuals. When spaces become congested, it leads to a reconsideration of the allocation of public space. Therefore, Webster (2007: 87) continues to argue that "the ability to separate rights to various valuable and congestible attributes of an urban space is the first step to good physical and institutional urban design". This would require a set of feasible design and governance solutions and thus a reconsideration of ownership and management practices. The cooperation between individuals can be organised either by a central planning authority or by decentralised bilateral transactions. This raises questions as to whether different types of urban space are best governed by a public entity, private agency or a partnership between the two. This would also depend on the gradual evolution of public space over time, influenced by changing tastes, demands and conflicts, which, in turn, could imply a diversification of institutions or governance models (Webster 2007: 88, 96). This raises many questions related to the transformation of different types of public space in various parts of the world. Do they change in similar ways? If so, what would be required in terms of feasible design and governance solutions in increasingly polarised and security-conscious societies where different groups of people have changing and often conflicting needs?

\section{CONTEXT, STUDY BACKGROUND AND METHODOLOGY}

The City of Tshwane, as the municipal area is known, incorporates the older city of Pretoria and is the capital city of South Africa. The municipal area includes about 2.9 million people spread out over a total land area of $6298 \mathrm{~km}^{2}$ at a population density of 464 people $/ \mathrm{km}^{2}$. Due to the presence of 134 diplomatic missions and 26 international organisations, it has the second largest concentration after Washington D.C. It is also the 'intellectual' capital, as $90 \%$ of all research and development in the country is conducted in the city (Tshwane 2055 Strategy, 2013: 42). However, while the city is home to a large diplomatic service, major industries and national government accommodating the administrative seat of government, 135,645 households have no income and the unemployment rate is $24 \%$ (Tshwane 2055 Strategy, 2013: 42). It is thus also a city of inequality. Consequently, the public realm is often characterised by rivalry and the transformation of public space through various forms of privatisation and exclusion, where more middleand higher income users become reluctant to share these spaces with homeless people and beggars (Landman, 2015).

In this context, a new type of quasi-public 'plaza' is emerging in South Africa aimed at the consumer citizen. Although these spaces are trying to imitate typical characteristics of public spaces to enhance their attractiveness, they are mostly associated with larger spaces of consumption such as shopping malls. At the same time, they are starting to function as gathering places for mobile suburbanites or, in other words, residents who utilise their private cars to obtain access to the shopping malls. Given this, it is important to understand their nature and implications for the city and the public. This is supported by Langstraat and Van Melik (2013) who maintain that one should not only study public spaces that are part of big flagship projects and spaces in the inner city, but also potential gathering spaces in the suburbs. In addition, Jackson (1998) calls for situated analysis of context-specific places to understand the local dynamics, especially beyond the Anglo-American focus, that have dominated public-space research to some extent (Langstraat \& Van Melik, 2013; Allan, 2006). Furthermore, while pseudo-public spaces have been studied in Johannesburg in the form of Melrose Arch (Murray, 2013), this large-scale development is different to the new type of small outdoor 'plazas' that are being developed as part of shopping malls in Pretoria.

The article focuses on three typical examples of emerging pseudo-public 'plazas' in the City of Tshwane, namely Lynnwood Bridge, Woodlands Mall and the Irene Village Mall. In order to gather data for the study, all three spaces were visited on a regular basis at different times of the day and on various days of the week, utilising research methods such as spatial and participant observation. Guided by the framework summarised in Appendix A, data was collected regarding the function, form and meaning of these spaces. This included a detailed spatial analysis and recording of the form of each space and careful observation of the use of these spaces by various groups at different times of the day and week.

\section{THE CHARACTERISTICS OF A NEW TYPE OF QUASI-PUBLIC 'PLAZA' IN SOUTH AFRICA}

All three developments are located in the south-east of the City of Tshwane next to major highways or through-routes (Figure 2). Lynnwood Bridge is located next to the major national highway (N1), whereas Irene Village Mall is situated next to the R21 linking the CBD of Pretoria to the OR Thambo International Airport. Woodlands Mall is located on a major through-route, Garsfontein Road, connecting the N1 with the R25. All three developments, therefore, offer good accessibility for private transport and ample parking space. 


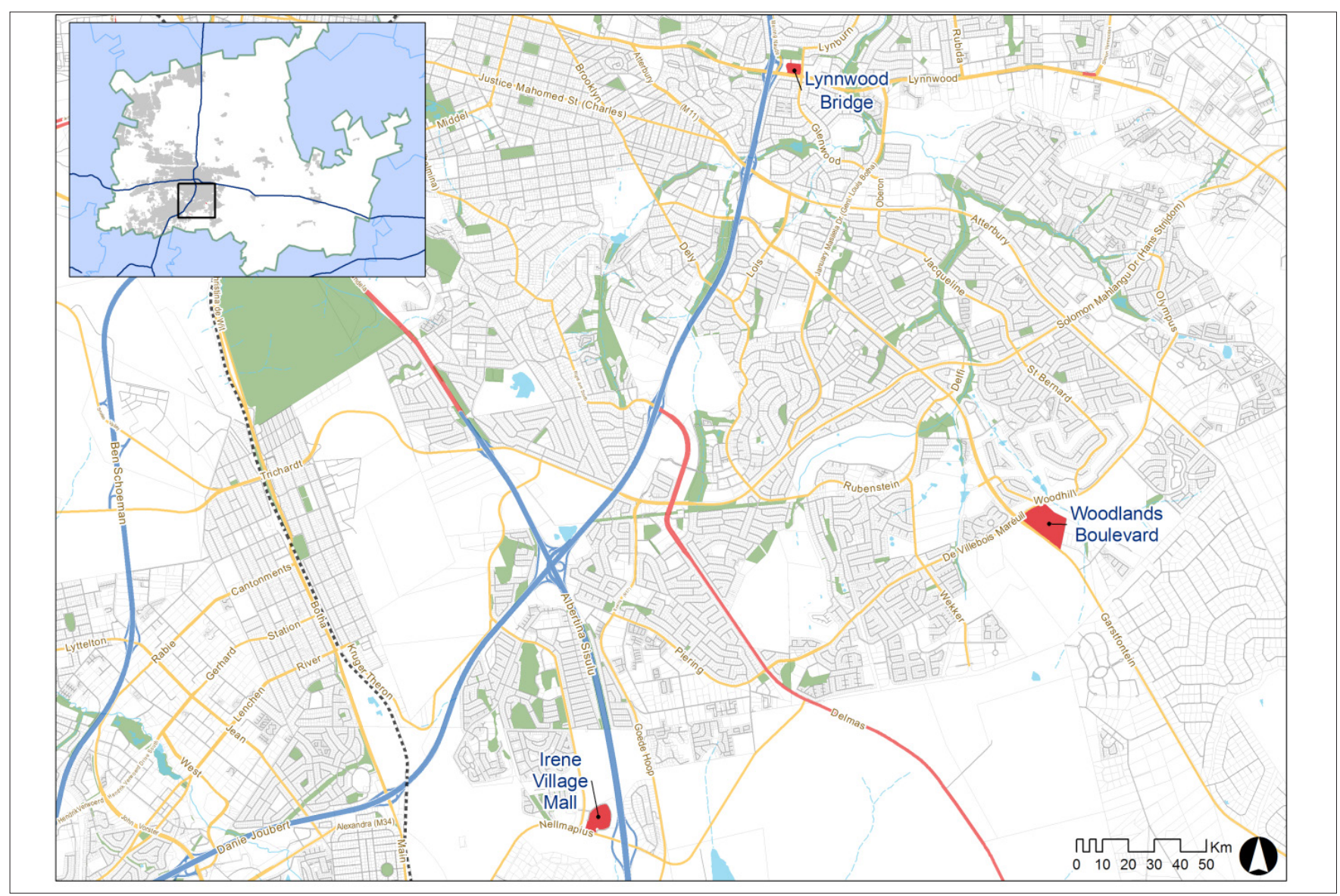

Figure 2: The location of the three shopping malls in the City of Tshwane Source: Produced by Darren Nel, 2016

They also offer a diverse set of activities and destinations. Lynnwood Bridge includes a hotel, two major office blocks, a theatre, exclusive shops and a food store. Around the central open space, there is a range of small clothing, jewellery and bookstores that cater for middle- to high-income groups, as well as a variety of restaurants (Figure 3 ). The theatre acts as a major attractor to the centre and is also served by the open space. Woodlands Mall predominantly serves the new suburbia and gated townhouse complexes and estates on the outer periphery of the city. The central outdoor space is surrounded by restaurants and offers access to smaller shops. The cinema acts as a major attractor, drawing people through the space, while the children's play area accommodates smaller children (Figure 4). As is the case with Woodlands Mall, the Irene Village Mall is also located on the periphery of the built-up area. The central plaza is lined with various restaurants situated behind trees and flanked by shops on the far ends (Figure 5). The larger shopping mall includes two major retail stores, smaller clothing and jewellery shops, cosmetic and toys stores as well as bookstores.

In Woodlands and Irene Village Mall, the buildings subdue the noise of the surrounding parking lot and highway. The space in Lynnwood Bridge is raised on a platform above the parking garage and, therefore, completely separated and protected from Lynnwood and Daventry Roads and the activities taking place there. All three spaces are designed for pedestrians. Outside and below, however, large parking areas and fences send out contradictory signals to pedestrians and emphasise carbased connectivity.

The transaction base is another important item in all three spaces. The focus is on consumption: to eat, to shop and/or to go to the theatre or movies. Yet, in a more figurative sense, the consumption is also linked to the 'consumption' of elements of beauty and this is perhaps one of the fewer activities in which those without money can engage. Given this, the organisation and treatment of the built form is very important.

All three spaces are enclosed and internally focused, offering limited views to the outside. The central plaza in Lynnwood Bridge has an irregular form with four branches to the side (Figure 6). The one branch offers a secondary gathering space for two additional restaurants and a view to Lynwood Road from a raised platform. Woodlands Mall is a more conventional shopping mall with covered walkways and shops on either side. The open 'plaza' offers only one framed view to the outside, which also provides an entrance from the parking area in the north (Figure 7). In Irene Village Mall, the designers aimed to create an alternative type of mall, incorporating a number of New Urbanist principles in an attempt to recreate a village atmosphere. 


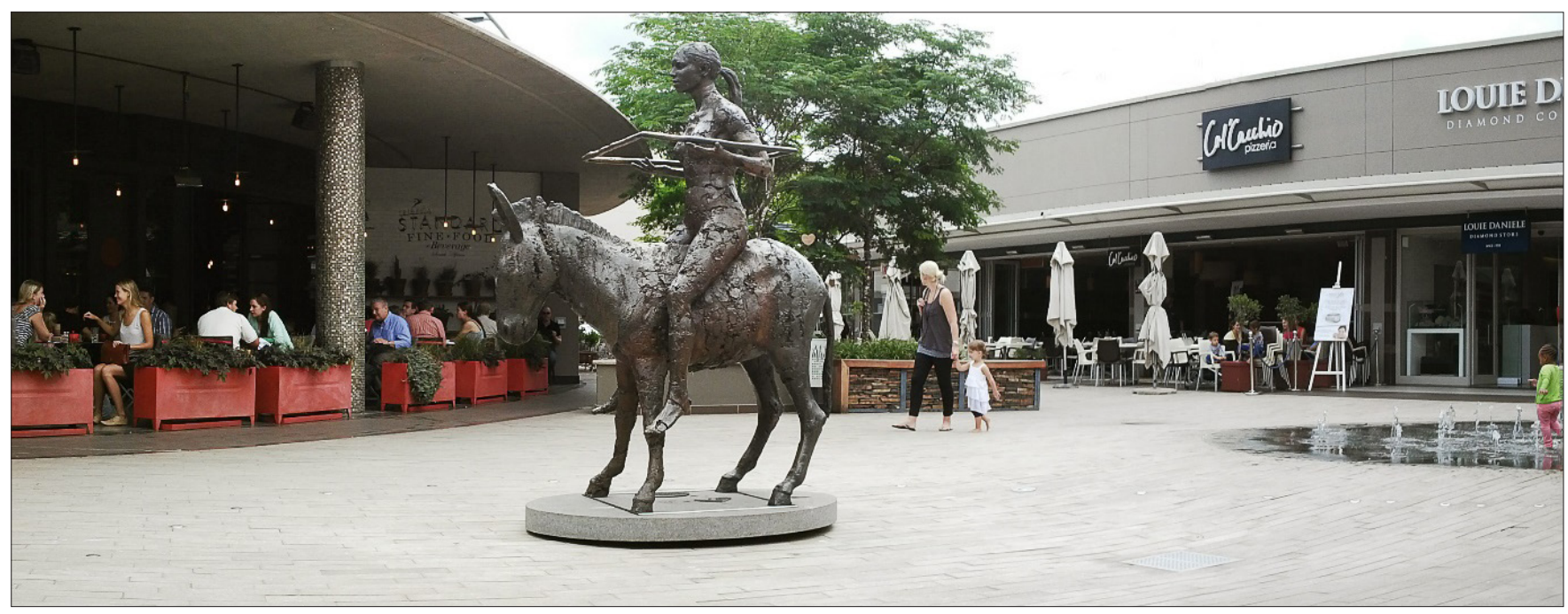

Figure 3: One side of the main gathering place in Lynnwood Bridge Source: Author

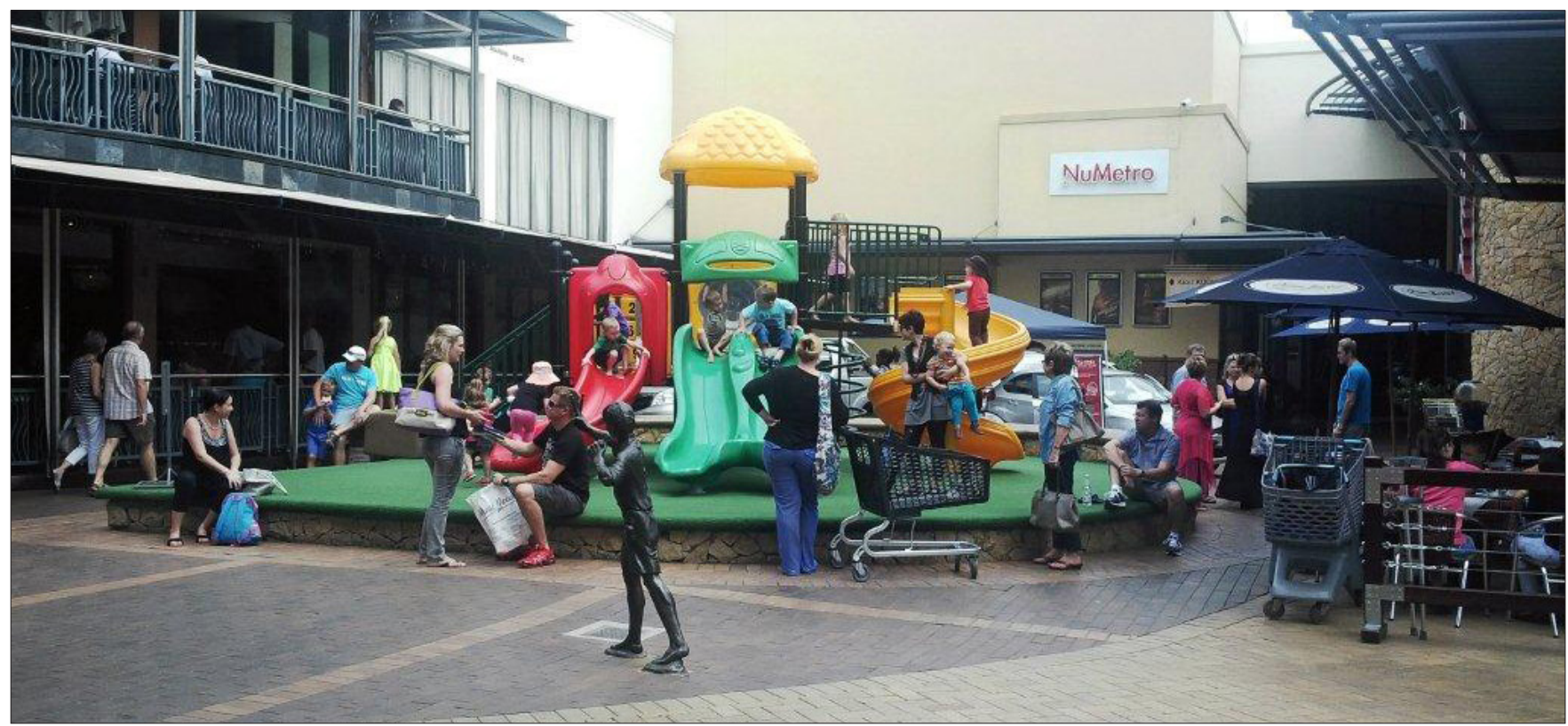

Figure 4: One side of the main gathering place in Woodlands Mall with restaurants in the background Source: Author

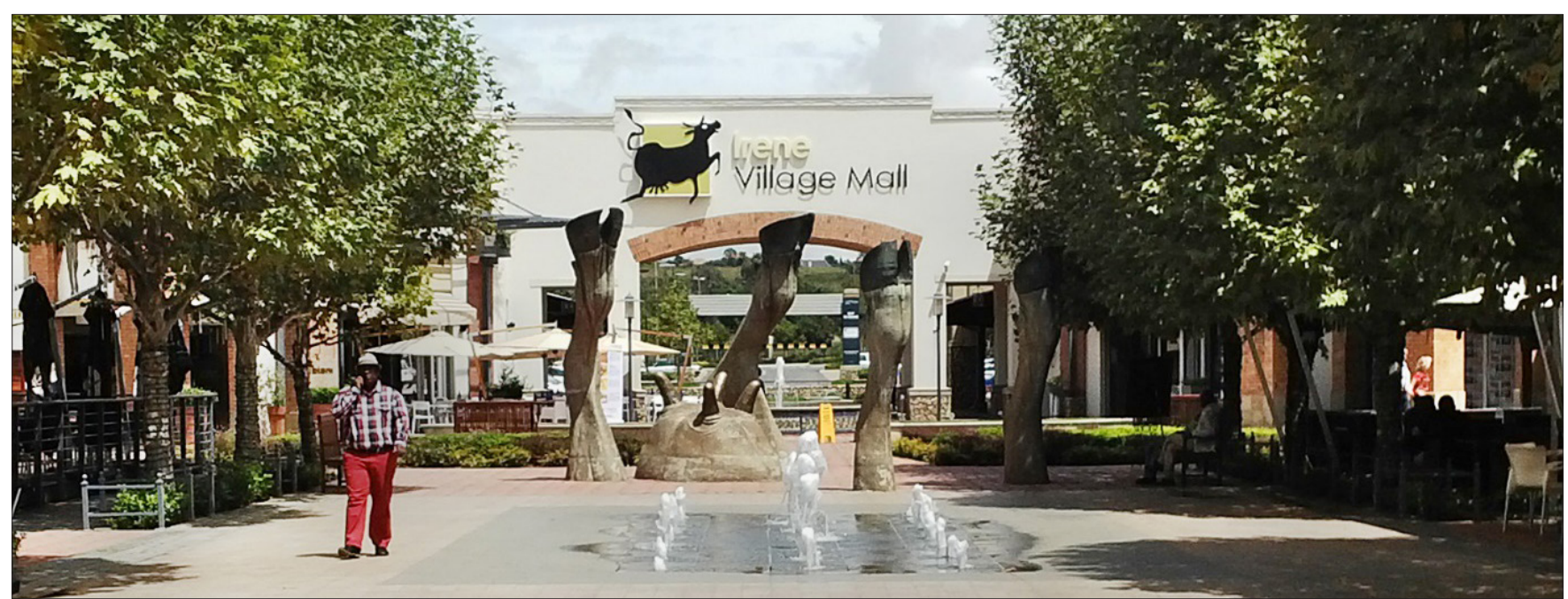

Figure 5: The main gathering space in the Irene Village Mall with the gateway in the background Source: Author 


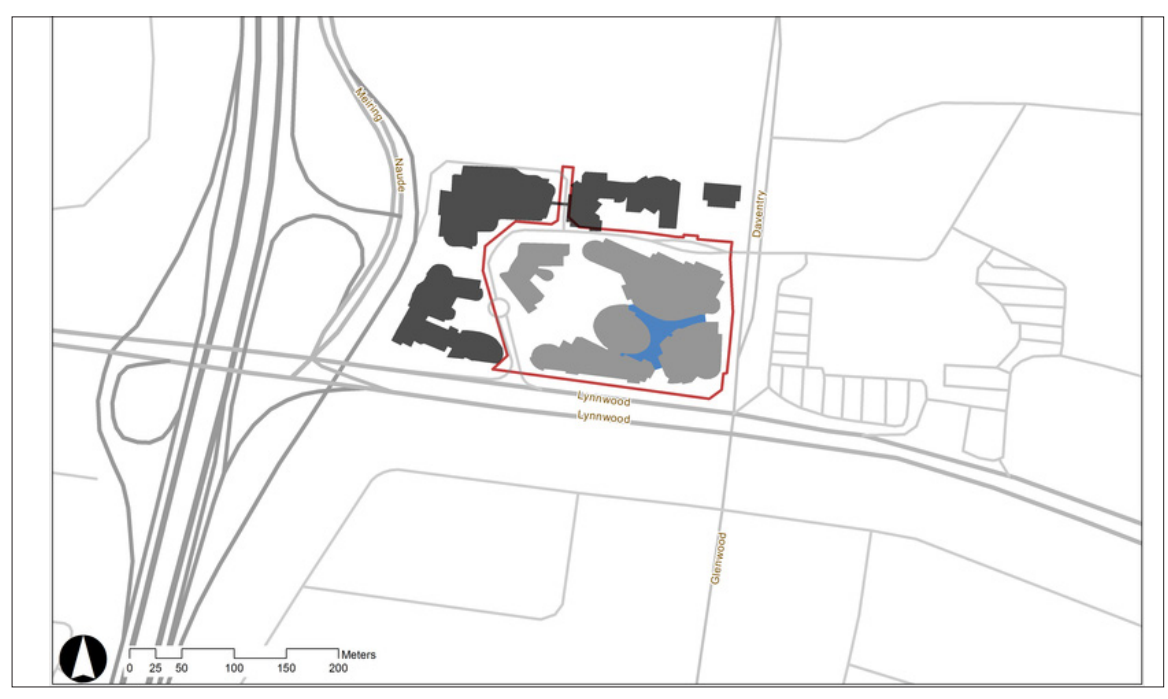

Figure 6: The form and location of the quasi-public space in Lynnwood Bridge Source: Produced by Darren Nel, 2016

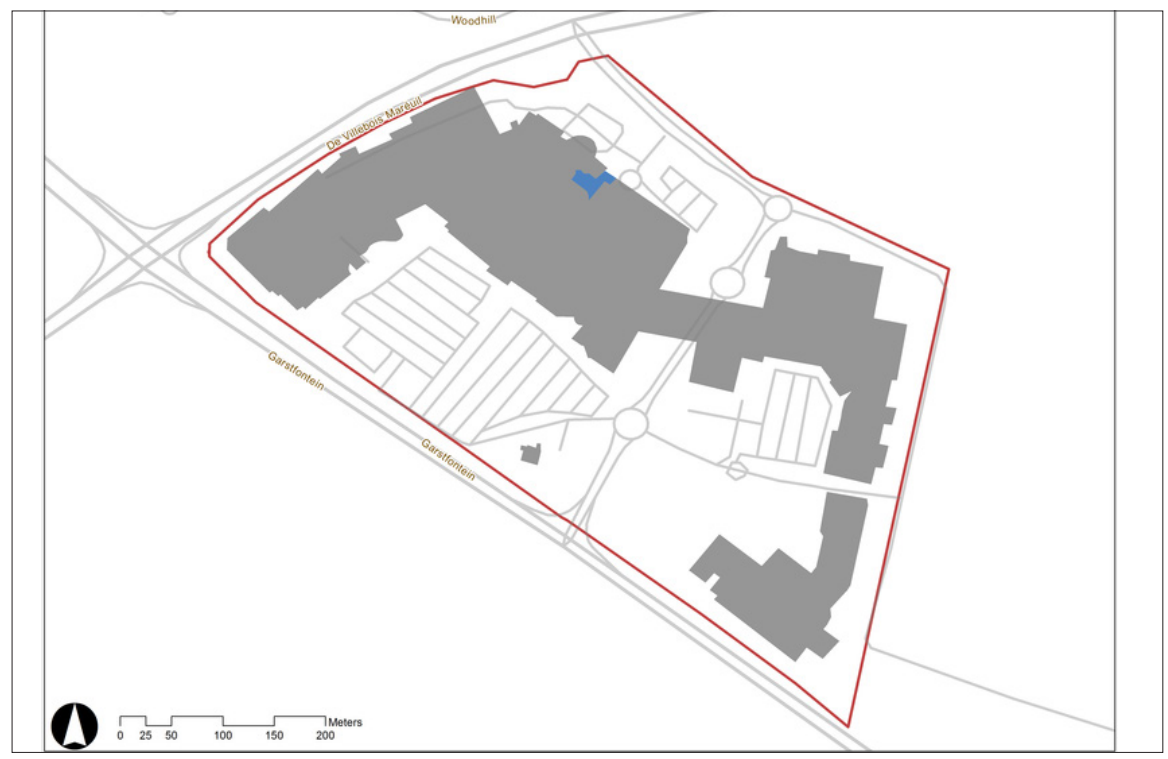

Figure 7: The form and location of the quasi-public space in Woodlands Mall Source: Produced by Darren Nel, 2016

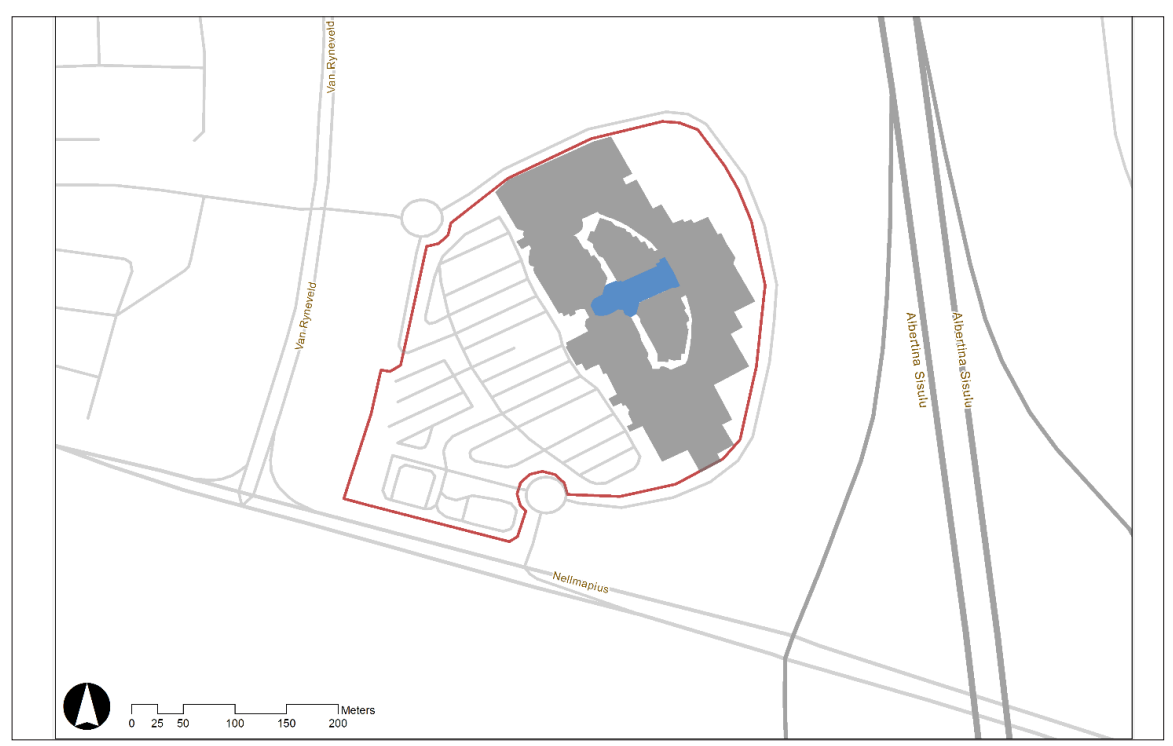

Figure 8: The form and location of the quasi-public space in Irene Village Mall Source: Produced by Darren Nel, 2016
The internal walkways are designed to imitate small open-air village lanes lined with shops, leading to a large central 'plaza' that is also open to the sky (Figure 8). In all three spaces, the shops and restaurants have glass facades to provide continuous visibility. The designs of the plazas also reflect a human scale and a high aesthetic quality.

The effective capacity of all three spaces is moderate. In Lynnwood Bridge, the space only caters for consumers, as the restaurants provide the only seating. Occasionally, however, people would make use of the walls of the plant containers to briefly sit down. This is slightly better in Woodlands Mall, where, apart from the seating offered by six restaurants and coffee shops, one bench is provided close to the children's play area. The edge of the children's play area is often used as de facto seating (Figure 9). The effective capacity and level of inclusivity in the open space in Irene Village Mall is much better, as seating is not only provided by the restaurants. Rows of benches are placed under the trees in front of the restaurants where people can watch children playing or others walking past.

The incorporation of vegetation also differs. In Lynnwood Bridge, large plant containers with shrubs and trees provide shade and add a softer touch to the hard open space. This is further enhanced by the water feature that is utilised by small children as a de facto play space in warmer weather (Figure 10). By contrast, the only sign of vegetation in the Woodlands Mall space is a large pot with a small tree placed at the entrance to one of the restaurants. The central gathering space in Irene Village Mall features large trees that offer shading and enclose the space, with low shrubs next to the restaurants and a water fountain that soften the space (Figure 11).

Sculptures offer a sense of place and identity in all three gathering spaces. In Lynnwood Bridge, a few characteristic sculptures allow for visual engagement, while the lighting on the facades contributes to a warm and safe atmosphere in the evening. 


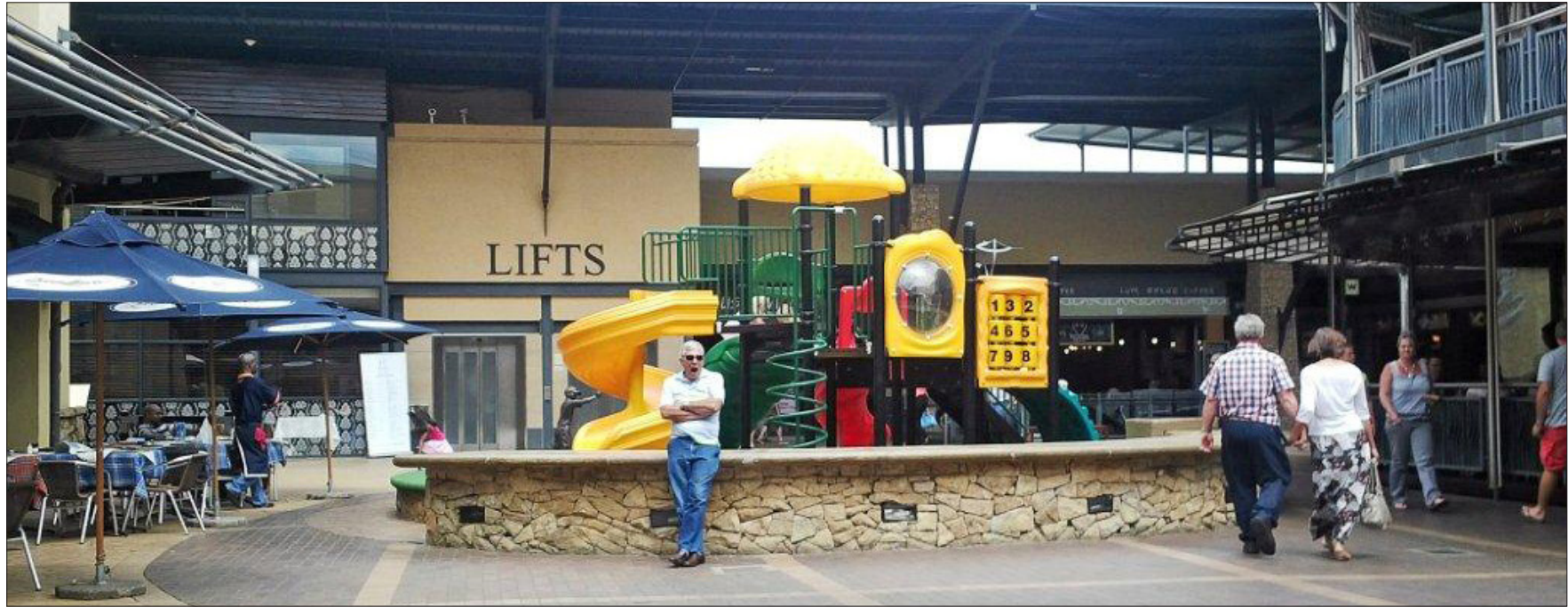

Figure 9: Woodlands Mall plaza: Looking towards the other side with restaurants and shops in the background and people sitting on the low wall

Source: Author

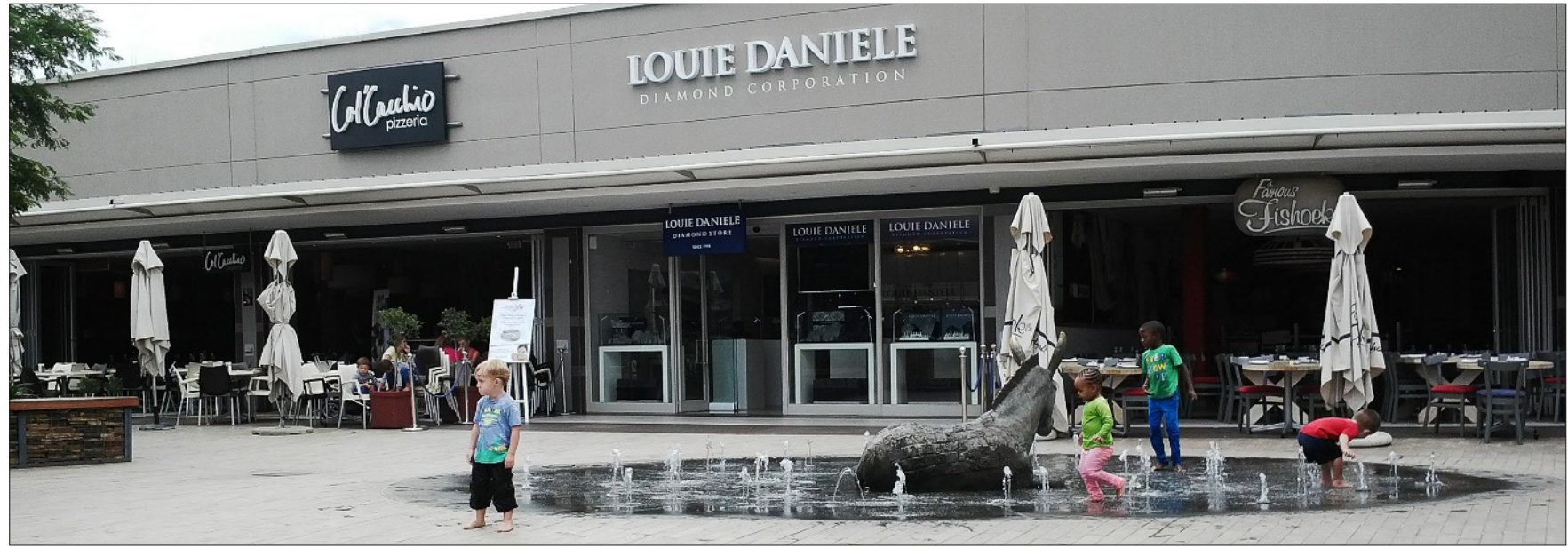

Figure 10:A prominent sculpture with fountain that is often used by children as a play space in the Lynnwood Bridge plaza Source: Author

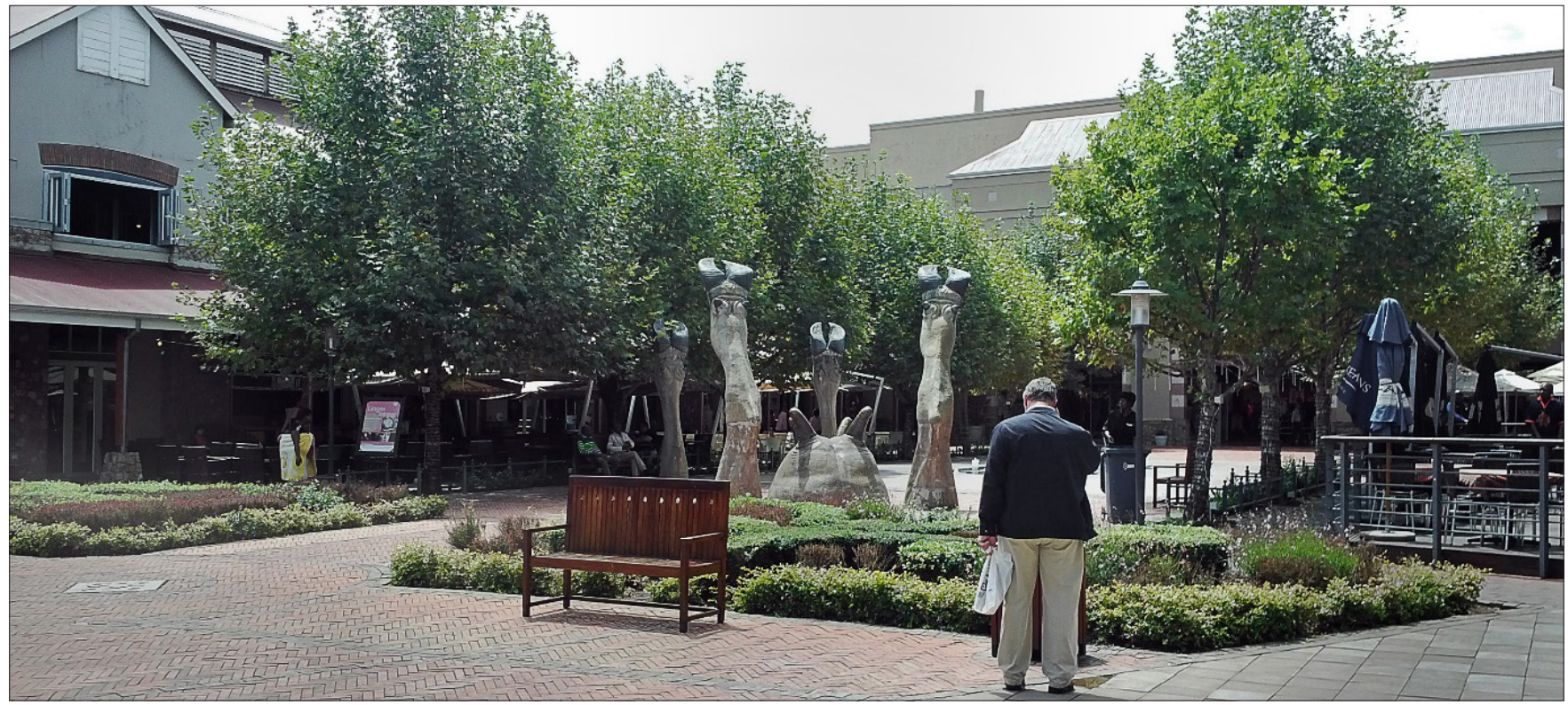

Figure 11:Looking from the other side of the Irene Village Mall plaza towards the tree-lined space with restaurants on both sides and a large sculpture in the centre

Source: Author 
The two sculptures of small children situated near the bench in Woodlands Mall offer a sense of playfulness. The entire Irene Village Mall and plaza, including the architecture, reflects the 'village' theme. This is further enhanced by the sculptures that mostly depict cows in various postures.

These items characterising the function and form of the spaces also contribute to a sense of meaning. The image of the Lynnwood Bridge 'plaza' is that of a high-class shopping area supported by major restaurants. The smell of food, products displayed in the windows and advertisements of upcoming performances all contribute towards drawing in the consumer. Similarly, the Woodlands Mall is marketed as "The Fashion Capital" of Pretoria, reflecting its target market and focus, as well as social status. The sensory experiences are all focused on consumption: the smell of food at the restaurants that draws people closer; the advertisements of food or other products on the walls and the products themselves that are displayed in the windows. The identity and image of the plaza in Irene Village Mall is that of the central place in a small village. This also symbolises life in Irene and serves as a memory of the history of the area, when Irene was still a small village outside Pretoria where people farmed with cattle in the surroundings. The experience offers some elements of village life, but the real nature of a shopping mall cannot be hidden completely. None of the three spaces offer additional information regarding community life, as the main focus remains centred on retail and entertainment. In Lynnwood Bridge, there are some notices of forthcoming events in the theatre or products available in the shops, but this remains limited. Yet, all three spaces offer a safe environment with no sense of fear. This is supported by the presence of CCTV cameras and private security guards at the entrances and in the parking areas.

The discussion indicates that, while these new types of 'plaza' incorporate many of the characteristics of successful public places, a few are neglected or only partly accommodated. Accessibility and diversity are accommodated rather selectively and pedestrians only receive priority inside the spaces. The focus of these spaces also tends to be internal and, therefore, visual permeability to the surroundings is limited, while connectivity and accessibility are poor and predominantly car-based. The provision of outdoor furniture is generally lacking, as the intention remains that people should use the restaurants. These quasi-public consumption spaces also differ from more conventional public spaces in the sense that access is closely monitored with a strong security presence and users tend to be selective, either due to control measures or by their own choice and ability to 'fit in' and pay for goods and services.

\section{THE IMPLICATIONS OF QUASI-PUBLIC SPACES FOR CITY PLANNING AND URBAN DESIGN}

A number of planners and urban designers (Ellen, 1999; Madanipour, 1999; Carmona, 2010; LoukaitesSideris, 2010) have discussed the establishment of a quasi-public space that is over-managed, privately owned and linked to the notion of commodified space to protect consumers from users who are deemed undesirable and dangerous. Others have severely criticised a quasi-public space as the 'end of public space' (Sorkin, 1992). Yet, recently, authors have argued that, although they acknowledge the concerns related to the privatisation of public space and the exclusion of undesirables from pseudo-public spaces, this does not necessarily imply the end of public space (Allan, 2006; Langstraat \& Van Melik, 2013). Several authors have called for a more nuanced reading of public spaces, also by urban planners and designers, that would take into account various scales and complexities related to issues of publicness (De Maghalaes, 2010; Langstraat \& Van Melik, 2013), reconsider exclusion and inclusion in pseudo-public space (Allan, 2006), and acknowledge that there are different user preferences in the city related to public space (Jackson, 1998; Carmona \& Wunderlich, 2003).

One such a preference may be for spaces of consumption in a more controlled environment. Therefore, as South African cities have changed, so has public space to accommodate new preferences and tastes. As the level of rivalry related to use and users in conventional public spaces increases (Landman, 2015; 2016), new types of space evolve to be excludable and non-rival. These spaces are what Webster (2007) classifies as a 'club' good that remains stable as long as the governing organisation, i.e. the Mall Management, can maintain control over the quantity and quality of the space available and the consumers.

Yet, it also becomes apparent that these spaces are not only accommodating 'consumption in space', but also 'consumption of space'. Carmona and Wunderlich (2003: 140) distinguish between these concepts, where the first refers to spaces in which activities of consumption such as purchasing goods, food or services occur and the latter to the space itself that becomes a spectacle to be consumed like a product. This deliberate consumption of places can also be linked to the desire of ordinary citizens to "have interesting experiences" (Hajer \& Reijndorp, 2001: 49-50) or simply to the fact that "the shopping experience has become the urban experience for many people" (Christopherson, 1994: 414). Therefore, the "experience of the space itself provides the commercial offering" (Allan, 2006: 451) and, in many instances, cities and perhaps shopping centres compete with each other to create opportunities for these 'experiences' (Carmona \& Wunderlich, 2003: 141). In this respect, the built environment and urban design play an important role through the incorporation of characteristics of successful public places in facilitating these experiences and revealing what Allan (2006) refers to as the ambient power present in public spaces. In the three spaces discussed, power 
is not so much expressed by security gates and guards, but rather by an unmarked presence, in which the space itself is experienced as the expression of power. In this case, ambient power refers to "something about the character of an urban setting - a particular feeling - that affects how we experience it and which in turn induce[s] certain stances which we might otherwise have chosen not to adopt" (Allan, 2006: 445). In this way, the power of real estate is also visible in their ability to utilise urban design to offer various experiences in a controlled environment, as opposed to the somewhat unattractive and often degraded public open spaces in the City of Tshwane (Landman, 2015; 2016).

This raises many questions about the nature of quasi-public consumption spaces in contemporary cities, which have been criticised for being exclusive (Minton, 2006; Carmona, 2010), "apolitical" (LoukaitouSideris \& Banjeree, 1998: 291) and undemocratic (Mattson, 1999: 136). Some have argued that it may not be that straightforward and that the notions of "consumer citizenship" (Christopherson, 1994: 414) and, therefore, consumption space as well need to be carefully situated and socially differentiated. As noted by Jackson (1998: 188), it may not simply be a case of assuming that commodification and privatisation are inherently undemocratic and reactionary social processes, but would rather imply a context-specific understanding of different cases "to trace out specific contours of these processes in particular spaces and places". Amin (2008: 708) suggests that there is ample research indicating that contemporary trends towards urban retail and leisure can also facilitate individual friendship or public regard and that even the most commoditised forms of urban consumption have not displaced inquisitiveness and enchantment for others. In addition, he maintains that, in spite of a focus on consumption, public space remains a place for social recognition and acceptance of codes of civic conduct.
Therefore, returning to Allan's (2006: 454) notion of ambient power, quasi-public spaces do not always have to imply exclusion, but as he suggests can also involve the operation of seduction as a more inclusive force that may function instead or alongside more visual displays of power such as security guards, gates, CCTV cameras and so on. In line with Allan's argument, the new type of quasipublic consumption spaces that are emerging in Pretoria operate through enticement, suggestion and inclusion, where people are offered certain choices based on the degree of ambient qualities in a particular space. It, therefore, requires a more detailed understanding of inclusion and exclusion in public space and, hence, the level of publicness of these quasi-public spaces.

This places public authorities, planners and urban designers in a precarious position when they are required to recognise the different preferences and needs of various groups and simultaneously ensure access to public space as far as possible. Such a situation is especially contentious and problematic in a country such as South Africa, where these stakeholders and the public at large are trying to come to terms with a very segregated past. Perhaps a way forward for local authorities and urban designers working for the state would be to learn from these cases in terms of their successful incorporation of many of the characteristics of successful public spaces, while simultaneously giving special attention to issues of management and security without limiting the accessibility and level of publicness.

\section{CONCLUSION: NEO-TRADITIONAL CONSUMPTION SPACE OR CONTROLLED VILLAGE COMMONS?}

This article focused on the evolution of public space in South Africa and discussed the emergence of a smaller type of quasi-public plaza in the capital City of Tshwane, where the main focus is on consumption and control. However, these spaces tend to utilise many of the characteristics of successful public spaces in terms of their form and function. As such, they imitate or recreate a more conventional plaza in the context of a shopping mall.

However, there are subtle differences between these quasi-public consumption spaces and more conventional public plazas. First, these spaces specifically focus on retail and entertainment to entice and enhance consumption within these spaces. They display a wide variety of goods and services on offer and, therefore, draw people closer to engage with these, similarly to what has been observed by Allan (2006) in Berlin. Hence, the focus remains on consumption, but in the form of a new type of evolving space that resembles characteristics of more conventional neo-traditional and New-Urbanist spaces. Secondly, it is not only the consumption of goods and services that are important, but also the consumption of space, especially in the case of Irene Village Mall plaza. These spaces offer destinations where people can experience something of the older traditional spaces through the incorporation of specific items of form. In addition, they offer a place to gather collectively in suburbia - that generally lack plazas or squares of a more traditional nature - in a more formalised and safe space offering a variety of socio-economic opportunities. In this sense, they become a type of controlled village commons for the suburbs of the large metropolis; not as an ideal place to develop a sense of community or culture, but more as a place to engage in activities such as obtaining goods and services, meeting friends or colleagues, watching people, and engaging in a stimulating experience, which are reminiscent of some of the functions that used to occur in traditional public spaces. Thirdly, while they incorporate most of the characteristics of successful public places, these are somewhat reinterpreted. For example, while these spaces offer access to the public, it is mostly to a selective 
group that feels comfortable to go there and engage in the activities offered, linked to their ability to pay for goods and services. As suggested by Christopherson (1994: 414), diversity is reinterpreted to "include multicultural 'communities' and cultural 'diversity'". This selling of diversity and multicultural experience is, however, akin to a commodified version of diversity that is "not about traditions or need, but about surfaces - colours, styles and tastes that are all packaged in easily consumable forms". This is reflected in the new type of quasi-public plazas where the notion of diversity is being modified to include multicultural and multiracial patrons who are welcome in these spaces.

It is, therefore, not merely a matter of simple exclusion or inclusion, but perhaps more a case of voluntary participation and acceptance of the status quo. The experience offered by these quasi-public places is twofold: one of exclusion based on the inability to look the part and pay for goods and services, and one of inclusion based on the choice to engage with the space in a comfortable and secure way and consume what is on offer. This is not to negate concerns about accessibility and the publicness of these spaces, but only to show the multiple processes that take place simultaneously. Therefore, following Jackson's (1994) argument, the commodification and privatisation of these small plazas in South Africa may not be experienced as undemocratic and reactionary by the entire public. The article clearly indicated that many characteristics of successful public spaces, which are, in fact, supported and promoted by public authorities and urban designers, could be linked to these quasi-public consumption spaces in the sense that both 'consumption of space', with emphasis on form, and 'consumption in space', with emphasis on function, produce a range of experiences that have a particular meaning for different groups. These experiences of either a feeling of belonging and safety or alienation and displacement can be very direct when linked to physical security measures and the presence of guards or, much subtler, through the experience of the ambient qualities of these small plazas.

Therefore, in the final consideration of these new quasi-public consumption spaces, the real question is not whether they are neotraditional consumption spaces or a controlled village commons, as they include aspects of both, but rather whether planning should actively discourage or prevent them. There is a tendency among many urban designers and planners to dismiss shopping malls as too commercial and elitist. While there may be some elements of truth contained in this, another part of the truth is that suburbia and shopping malls will not disappear overnight. As such, the role of planners and urban designers may not simply be one of prevention or discouragement, but perhaps one of being more actively involved in the planning and design of these developments to encourage the incorporation of many characteristics of successful public spaces and greater integration and accessibility to the immediate surroundings.

\section{ACKNOWLEDGEMENTS}

The financial assistance (Grant no. 81213) of the National Research Foundation (NRF) towards the research is hereby acknowledged. Opinions expressed and conclusions arrived at are those of the authors and cannot be attributed to the NRF. The author would also like to thank Darren Nel for the production of the maps and diagrams; Dr Jacques du Toit for useful comments to a first draft of the paper, and the reviewers for their constructive comments.

\section{REFERENCES LIST}

ALEXANDER, C., ISHIKAWA, S. \& SILVERSTEIN, M. 1977. A pattern language: Towns, buildings, construction. New York: Oxford University Press.

ALLAN, J. 2006. Ambient power: Berlin's Potsdamer Platz and the seductive logic of public spaces. Urban Studies, 43(2), pp. 441-455. https://doi. org/10.1080/00420980500416982
AMIN, A. 2008. Collective culture and urban public space. City: Analysis of Urban Trends, Culture, Theory, Policy, Action, 12(1), pp. 5-24. https://doi. org/10.1080/13604810801933495

BANERJEE, T. 2001. The future of public space: Beyond invented streets and reinvented places. Journal of the American Planning Association, 67(1), pp. 9-24. https://doi. org/10.1080/01944360108976352

BERNEY, R. 2010. Learning from Bogotá: How municipal experts transformed public space. Journal of Urban Design, 15(4), pp. 539-558. https://doi.org/10.1080/13574809.2010 .502344

BLOMLEY, N. 2007. Civil rights meet civil engineering: Urban public space and traffic logic. Canadian Journal of Law and Society, 22(2), pp. 55-72. https://doi.org/10.1017/ S0829320100009352

BLUMENFELD, H. 1972. The modern metropolis: Its origins, growth, characteristics, and planning. Edited by Spreiregen. Cambridge, Massachusetts: P.D. MIT Press.

CANTER, D. 1977. The psychology of place. London: Architectural Press.

CARMONA, M. 2010. Contemporary public space: Critique and classification. Part One: Critique. Journal of Urban Design, 15(1), pp. 123-148. https://doi. org/10.1080/13574800903435651

CARMONA, M. \& WUNDERLICH, F.M. 2003. Capital spaces: The multiple complex public spaces of a global city. London: Routledge.

CARR, S., FRANCIS, M., RIVLIN, L.G. \& STONE, A.M. 1992. Public space. New York: Cambridge University Press.

CHRISTOPHERSON, S. 1994. The fortress city: Privatised spaces, consumer citizenship. In: Amin, A. (Ed). Post Fordism: A reader. Oxford: Basil Blackwell, pp. 409-427. https://doi. org/10.1002/9780470712726.ch14

DE MAGALHAES, C. 2010. Public space and the contracting out of publicness: A framework for analysis. Journal of Urban Design, 15(4), pp. 559-574. https://doi.org/10.1080/13574 809.2010.502347

EHRENFEUCHT, R. \& LOUKAITOUSIDERIS, A. 2010. Planning urban sidewalks: Infrastructure, daily life and destinations. Journal of Urban Design, 15(4), pp. 459-471. https://doi.org/10.10 80/13574809.2010.502333 
GAFFIKIN, F., MCELDOWNEY, M. \& STERRETT, K. 2013. Creating shared public space in the contested city: The role of urban design. Journal of Urban Design, 15(4), pp. 493-513. https://doi. org/10.1080/13574809.2010.502338

GEHL, J. 2010. Cities for people. London: Island Press.

GEHL, J. 2011. Life between buildings: Using public space. London: Van Nostrand Reinhold.

GIDDINGS, B., CHARLTON, J. \& HORNE, M. 2011. Public squares in European city centres. Urban Design International, 16(3), pp. 202-212. https://doi.org/10.1057/udi.2011.6

HAJER, M. \& REIJNDORP, A. 2001. In search of new public domain. Rotterdam: Netherlands Architecture Institute.

HAMILTON-BAILLIE, B. 2007. Shared space: Reconciling people, places and traffic. Built Environment, 34(2), pp. 161-181. https://doi.org/10.2148/ benv.34.2.161

HEDMAN, R. \& JASZEWSKI, A. 1984. Fundamentals of urban design. Washington, D.C.: American Planning Association Planners Press.

HESTER, R. 1993. Sacred structures and everyday life: A return to Manteo, North Carolina. In: Seamon, D. (Ed.). In dwelling seeing and designing: Toward a phenomenological ecology. New York: State University of New York Press, pp. 217-298.

HILLIER, B. 1996. Cities as movement systems. Urban Design International, 1(1), pp. 47-60. https://doi.org/10.1057/ udi.1996.5

JACKSON, P. 1998. Domesticating the street: The contested spaces of the high street and the mall. In: Fife, N.R. (Ed.). Images of the street: Planning, identity and control in public space. New York: Routledge, pp. 176-191.

JACOBS, J. 1961. The life and death of great American cities. New York: Vintage Books.

KOHN, M. 2004. Brave new neighborhoods: The privatization of public space. New York: Routledge.

KOSTOF, S. 1992. The City assembled: The elements of urban form through history. London: Thames \& Hudson.

LANDMAN, K. 2015. The nature and use of public open space in the City of Tshwane. Innovate, 10, pp. 91-94.
LANDMAN, K. 2016. The

transformation of urban space in South Africa and the role of urban design. Urban Design International, 21(1), pp. 78-92. https://doi.org/10.1057/ udi.2015.24

LANGSTRAAT, F. \& VAN MELIK, R. 2013. Challenging the 'end of public space': A comparative analysis of publicness in British and Dutch urban spaces. Journal of Urban Design, 18(3), pp. 429-448. https://doi.org/10.10 80/13574809.2013.800451

LLEWELLYN-DAVIS LTD. 2000. Urban design compendium. Prepared for English Partnership and the Housing Corporation. London: English Partnerships.

LOUKAITOU-SIDERIS, A. 2012. Addressing the challenges of urban landscapes: Normative goals for urban design. Journal of Urban Design, 17(4), pp. 467-484. https://doi.org/10.1080/13 574809.2012.706601

LOUKAITOU-SIDERIS, A. \& BANERJEE, T. 1998. Urban design downtown: Poetics and politics of form. Berkeley: University of California Press.

LOW, S. \& SMITH, N. (Eds). 2006.

The politics of public space. New York: Routledge.

MADANIPOUR, A. 1999. Why are the design and development of public spaces significant for cities? Environment and Planning B: Planning and Design, 26(6), pp. 879-891. https:// doi.org/10.1068/b260879

MADANIPOUR, A. (Ed.). 2010. Whose public space? International case studies in urban design and development. London: Routledge.

MATTSON, K. 1999. Reclaiming and remaking public space: Towards an architecture for American democracy. National Civic Renewal, 88(2), pp. 133144. https://doi.org/10.1002/ncr.88206

METHA, V. 2014. Evaluating public space. Journal of Urban Design, 19(1), pp. 53-88. https://doi.org/10.1080/1357 4809.2013.854698

MINTON, A. 2006. What kind of world are we building? The privatisation of public space. A report prepared by the Royal Institution of Chartered Surveyors. London: RICS.

MONTGOMERY, J. 1994. The evening economy of cities. Regenerating Cities (Issue 7), pp. 32-39.
MONTGOMERY, J. 1998. Making a city: Urbanity, vitality and urban design. Journal of Urban Design, 3(1), pp. 93116. MOUGHTON, C. \& MERTENS, M. 2003. Urban design: Street and square. $3^{\text {rd }}$ edition. Amsterdam: Elsevier Ltd.

MURRAY, M.J. 2013. The quandary of post-public space: New urbanism, Melrose Arch and the rebuilding of Johannesburg after apartheid. Journal of Urban Design, 18(1), pp. 119-144. https://doi.org/10.1080/13574809.2012 .739544

PUNTER, J. 1991. Participation in the design of urban space. Landscape Design, 200, pp. 24-27.

SALAT, S., LABBÉ, F., NOWACKI, C. \& WALKER, G. 2011. Cities and forms on sustainable urbanism. Paris: CSTB Urban Morphology Laboratory, Hermann.

SHORT, J.R. 1996. The urban order: An introduction to cities, culture and power. Cambridge: Blackwell Publishers.

SORKIN, M. (Ed.). 1992. Variations on a theme park: The new American city and the end of public space. New York: Hill and Wang.

TALEN, E. 2000. Measuring the public realm: A preliminary assessment of the link between public space and sense of community. Journal of Architectural and Planning Research, 17(4), pp. 344-360.

TIESDELL, S. \& OC, T. 1998. Beyond 'fortress' and 'panoptic' cities towards a safer urban public realm. Environment and Planning B: Planning and Design, 25(5), pp. 639-655. https:// doi.org/10.1068/b250639

TSHWANE 2055 STRATEGY. 2013. Developed by the City of Tshwane.

VARNA, G. \& TIESDELL, S. 2010. Assessing the publicness of public space: The star model of publicness. Journal of Urban Design, 15(4), pp. 575-598. WEBSTER, C. 2007. Property rights, public space and urban design. Town Planning Review, 78(11), pp. 81-101.

WHYTE, W.H. 1980. The social life of small urban spaces. Ann Arbor, Michigan: Edwards Brothers. 


\section{APPENDIX A}

Table 1: Characteristics of successful public spaces

\begin{tabular}{|c|c|c|c|}
\hline Categories & Items & Justification & Source \\
\hline \multirow{6}{*}{ Function } & Accessibility & $\begin{array}{l}\text { Offering access to different groups of people and a variety of activities, through } \\
\text { shared space that also allows democratic meetings, displays and protests. }\end{array}$ & $\begin{array}{l}\text { Blumenfeld (1972); Matson (1999); } \\
\text { Talen (2000); Blomley (2007); Gaffikin, } \\
\text { Mceldowney \& Sterett (2010); Madanipour } \\
\text { (2010); Gehl (2010); Metha (2014). }\end{array}$ \\
\hline & Diversity & $\begin{array}{l}\text { Facilitating social interaction and contributing to a sustainable district through } \\
\text { different types of activities such as mixed land uses, longer opening hours, different } \\
\text { types of markets and entertainment facilities that cater for a variety of needs. }\end{array}$ & $\begin{array}{l}\text { Jacobs (1961); Montgomery (1998); } \\
\text { Madanipour (1999); Carr, Francis, Rivlin \& } \\
\text { Stone (1992); Gehl (2011); Salat, Labbé, } \\
\text { Nowacki \& Walker (2011); Metha (2014). }\end{array}$ \\
\hline & $\begin{array}{l}\text { Events and } \\
\text { attractors }\end{array}$ & $\begin{array}{l}\text { Encouraging social interaction through events and attractors such as festivals, } \\
\text { fireworks, performances and celebrations. }\end{array}$ & Gehl (2011); Salat et al. (2011). \\
\hline & $\begin{array}{l}\text { Pedestrian and } \\
\text { vehicular flows }\end{array}$ & $\begin{array}{l}\text { Reducing the extent of vehicular traffic and enhancing pedestrian access through } \\
\text { well-developed sidewalks and street crossings together with public transport options } \\
\text { to promote safety and various modes of access. In some instances, shared spaces } \\
\text { may be appropriate where vehicles and pedestrians can share space based on } \\
\text { informal social protocols and negotiation. }\end{array}$ & $\begin{array}{l}\text { Whyte (1980); Car et al. (1992); Talen } \\
\text { (2000); Berney (2010); Ehrenfeucht \& } \\
\text { Loukaitou-Sideris (2010); Hamilton-Baillie } \\
\text { (2007), Metha (2014). }\end{array}$ \\
\hline & Noise and sound & Minimising unacceptable noise and allowing conversations to take place. & Whyte (1980); Gehl (2011). \\
\hline & Transaction base & $\begin{array}{l}\text { Promoting sufficient levels of wide-ranging economic activity to facilitate economic } \\
\text { exchange such as retail and entertainment to satisfy basic needs. }\end{array}$ & $\begin{array}{l}\text { Blumenfeld (1972); Whyte (1980); } \\
\text { Montgomery (1994; 1998); Metha (2014). }\end{array}$ \\
\hline \multirow{9}{*}{ Form } & Connectivity & $\begin{array}{l}\text { Facilitating greater connection to surrounding environments through good location } \\
\text { and connection to the city's movement patterns and allowing different types of } \\
\text { people, including those with wheelchairs, prams and trollies to freely enter and use } \\
\text { public space without obstructions. }\end{array}$ & $\begin{array}{l}\text { Hillier (1996); Madanipour (2010); } \\
\text { Varna \& Tiesdell (2010); Gehl (2011); } \\
\text { Metha (2014). }\end{array}$ \\
\hline & Permeability & $\begin{array}{l}\text { Allowing visual contact through unhindered sightlines to surrounding areas and } \\
\text { within the public space to encourage opportunities for watching people, events and } \\
\text { to encourage safety. }\end{array}$ & $\begin{array}{l}\text { Jacobs (1961); Gehl (2010); Moughton \& } \\
\text { Mertens (2003). }\end{array}$ \\
\hline & Built form & $\begin{array}{l}\text { Creating positive 'outdoor rooms' through physical definition and a sense of } \\
\text { enclosure. The boundaries should have soft edges that are active, offer protection } \\
\text { against the weather and accommodate different zones of exchange and experience } \\
\text { through edge elements such as covered verandas or porticos, columns, bollards } \\
\text { and low walls that allow people to pause. }\end{array}$ & $\begin{array}{l}\text { Alexander et al. (1977), Moughton \& } \\
\text { Mertens (2003); Madanipour (1999, 2010); } \\
\text { Gehl }(2010,2011) \text {, Metha }(2014) .\end{array}$ \\
\hline & Aesthetic quality & $\begin{array}{l}\text { Encouraging high-quality buildings that are open to the outside with transparent } \\
\text { components that ensure transitions between public and private areas and have } \\
\text { the potential to contribute to a sense of place and safety. Creating plazas with an } \\
\text { intense three-dimensional quality through a moderate size and a uniform height of } \\
\text { the buildings. }\end{array}$ & $\begin{array}{l}\text { Hedman \& Jaszewski (1984); Cullen, } \\
\text { cited in Gehl (2010); Salat et al. (2011); } \\
\text { Gehl (2011). }\end{array}$ \\
\hline & Scale and size & $\begin{array}{l}\text { Promoting a human scale and, where appropriate, incorporating smaller spaces to } \\
\text { maintain quality and avoid impersonal space. Encouraging dimensions for a plaza } \\
\text { that does not exceed 1:3 to optimise the three-dimensional quality. }\end{array}$ & $\begin{array}{l}\text { Blumenfeld (1972); Alexander et al. } \\
\text { (1977); Hedman \& Jaszewski (1984); } \\
\text { Whyte (1980); Gehl (2010); Madanipour } \\
\text { (2010); Salat et al. (2011). }\end{array}$ \\
\hline & Shape & $\begin{array}{l}\text { Focusing on simplicity of form to permit the plaza to be experienced in its } \\
\text { entirety. Encouraging the incorporation of focus points to facilitate orientation and } \\
\text { importance, utilising sculptures or prominent architectural elements. }\end{array}$ & $\begin{array}{l}\text { Hedman \& Jaszewski (1984); Moughton \& } \\
\text { Mertens (2003); Gehl (2010; 2011). }\end{array}$ \\
\hline & $\begin{array}{l}\text { Intensity and } \\
\text { effective capacity }\end{array}$ & $\begin{array}{l}\text { Promoting sufficient density to support economic activity and accommodate } \\
\text { effective capacity according to the use, the context, the micro-climate and the } \\
\text { attractiveness without making the space too big. }\end{array}$ & $\begin{array}{l}\text { Whyte (1980); Moughton \& Mertens } \\
\text { (2003); Gehl (2010). }\end{array}$ \\
\hline & $\begin{array}{l}\text { Landscaping and } \\
\text { lighting }\end{array}$ & $\begin{array}{l}\text { Contributing to opportunities for visual and physical attraction through the inclusion } \\
\text { of features such as works of art, water, vegetation and good lighting, while } \\
\text { considering the different needs of children, adults and the elderly. }\end{array}$ & $\begin{array}{l}\text { Alexander et al. (1977); Gehl (2010; 2011); } \\
\text { Whyte (1980); Berney (2010). }\end{array}$ \\
\hline & Furniture & $\begin{array}{l}\text { Offering sufficient comfortable and semi-protected places to sit in the sun and } \\
\text { shade; both close to and further away from the pedestrian flows; accommodating } \\
\text { opportunities for conversation through clustering of furniture or moveable chairs or } \\
\text { performance through a raised platform. }\end{array}$ & $\begin{array}{l}\text { Alexander et al. (1997); Whyte (1980); } \\
\text { Gehl (2010). }\end{array}$ \\
\hline \multirow{5}{*}{ Meaning } & Identity & $\begin{array}{l}\text { Incorporating physical elements such as historical buildings, landmarks, art works } \\
\text { and greenery, as well as meaningful activities to allow people to identify with a place } \\
\text { through interest and participation. }\end{array}$ & $\begin{array}{l}\text { Lynch (1960); Montgomery (1998); Talen } \\
\text { (2000); Madanipour (2010); Metha (2014). }\end{array}$ \\
\hline & $\begin{array}{l}\text { Image and } \\
\text { aesthetics }\end{array}$ & $\begin{array}{l}\text { Encouraging a wide range of high-quality, durable buildings and open spaces to } \\
\text { create a coherent impression, facilitate a variety of sensory experiences, allow } \\
\text { physiological access and create a positive perception. }\end{array}$ & $\begin{array}{l}\text { Lynch (1960); Llewellyn-Davis (2000); } \\
\text { Gehl (2010); Madanipour (2010); } \\
\text { Metha (2014). }\end{array}$ \\
\hline & $\begin{array}{l}\text { Symbolism and } \\
\text { memory }\end{array}$ & $\begin{array}{l}\text { Promoting positive events to reflect values of tolerance and acceptance and } \\
\text { celebrating historical events through memorials or monuments. }\end{array}$ & $\begin{array}{l}\text { Montgomery (1998); Talen (2000); } \\
\text { Madanipour (2010). }\end{array}$ \\
\hline & $\begin{array}{l}\text { Interaction and } \\
\text { receptivity }\end{array}$ & $\begin{array}{l}\text { Encouraging social interaction and the establishment of meaningful connections between } \\
\text { the place, the people and the larger environment to facilitate positive experiences, } \\
\text { repeated visits, familiarity with the environment, specific associations with place and a } \\
\text { sense of collective and/or symbolic ownership, also referred to as receptivity. }\end{array}$ & $\begin{array}{l}\text { Car et al. (1992); Montgomery (1998); } \\
\text { Hester (1993); Metha (2014). }\end{array}$ \\
\hline & Knowledgeability & $\begin{array}{l}\text { Facilitating different informal networks and sources of information to promote } \\
\text { associational activity and the development of a sense of community. }\end{array}$ & Montgomery (1998); Metha (2014). \\
\hline
\end{tabular}

